\title{
Terrys in Spain and Latin-America: Exile and Rise of an Irish Merchant Family
}

\author{
Beatriz García-Álvarez de la Villa \\ $\mathrm{PhD}$ candidate, U. of Oviedo, Spain \\ Kevin Terry \\ Cloyne Literary and Historical Society, Ireland
}

Copyright (c) 2016 by Beatriz García-Álvarez de la Villa and Kevin Terry. This text may be archived and redistributed both in electronic form and in hard copy, provided that the authors and journal are properly cited and no fee is charged for access.

\begin{abstract}
This paper examines a Cork merchant family, Terry, with particular attention to the causes of their exile to Spain about 1700. Their significant sway in the civic and commercial affairs of Cork City at the beginning of the $17^{\text {th }}$ century, and their downfall by the mid $17^{\text {th }}$ century due to the impact on Catholic families of The Cromwellian Wars are detailed. After their exile to Spain, the success of this Irish family is linked to the recognition by the Spanish crown of their proofs of nobility, and the rights they gained to trade with the Indies. Their descendants quickly rose to influential positions in Spain and in South America where they moved to during the $18^{\text {th }}$ century.
\end{abstract}

Key Words. History, Terry, Merchant, Exile, Genealogy, Irish Americans, Irish Spanish.

Resumen. En este artículo se examina una familia comerciante de Cork, Terry, con especial atención a las causas de su exilio a España a principios del s. XVIII. Su importante papel en la sociedad y comercio de la ciudad de Cork a principios del s. XVII y su declive a mediados del s. XVII a causa del impacto de las guerras de Cromwell sobre las familias católicas son detalladas. A partir de su exilio a España, el éxito de esta familia irlandesa está vinculado al reconocimiento de sus pruebas de nobleza por la corona española y al derecho ganado para comerciar con las Indias. Sus descendientes alcanzaron rápidamente posiciones influyentes en España y también en América del Sur donde se extendieron a lo largo del s. XVIII.

Palabras clave. Historia, Terry, comerciante, exilio, genealogía, irlandés-americano, irlandés-español.

\section{Introduction}

In recent years the role played by foreign families in the modern and contemporary history of Spain has been increasingly recognized by historians (Oscar Recio 2012). The most numerous groups were French, Genoese, Flemish and Irish who settled in colonial Cadiz during the $17^{\text {th }}$ and $18^{\text {th }}$ centuries. According to Bustos (2005: 141), the Irish community represented 18 percent of foreigners in Cadiz by 1750 and were the third most important colony after the Genoese and French. This work traces the history of a noble Irish family from Cork, the Terrys, since 1600. Following a long family tradition marked by a strong influence in commercial, civil and ecclesiastic affairs in their home country, the Terrys lost power and most of their possessions during The Cromwellian wars. This prompted a number of them to go into exile to Spain during the first half of the $18^{\text {th }}$ century, where they achieved remarkably rapid social and economic ascent. Particular attention is given to the origin and accomplishments of some prominent Terrys in military, diplomatic, and commercial affairs in $18^{\text {th }}$ and $19^{\text {th }}$ century Spain. Our study of the genealogy of these Terrys in Cadiz and Malaga illuminates their origins and family relationships. Three family 
branches can be distinguished: two of which arrive in Cadiz directly from Ireland, whereas a third branch came from Genoa.

\section{Historical Context of the Early $17^{\text {th }}$ Century: The Constitutional Struggle (1603-1641)}

In 1600, there were three distinct groups in Ireland, Gaelic Irish, Old English and New English. ${ }^{1}$ The vast majority of Gaelic Irish were rurally based. Towns were not characteristic of Gaelic lordships, except for Episcopal centres and the unusual exception of the O'Reilly's settlement at Cavan (Foster 1988: 16). The towns existing in 1600 were often imposed on older foundations or sited at a port or estuary. Franchises and liberties were extensive by English standards. The freemen of these towns tended to be aristocratic merchants rather than craftsmen: Old English burgher families or local gentry who had migrated inside the walls.

On Queen Elizabeth's death, James VI of Scotland became King James I of England. James was a son of the Catholic Mary Stuart. In expectation that he would show himself well disposed towards his mother's faith, the Irish recusants, i.e. those who refused the Oath of Supremacy of the King (or Queen) as Head of the Church, looked forward hopefully to his reign. It was among the Old English, and not among the natives, that this expectation was highest (Beckett 1966: 46).This was the case in Cork City, where the delay in proclaiming the new King was intended to impress upon the new monarch the seriousness of the opposition of Catholics to the law compelling them to attend Protestant worship. One of the ringleaders to the opposition was Edmund Terry $^{2}$ (Hackett 2001: 116).

1. The term Old English, or Sean-Ghaill, was commonly used in the early $17^{\text {th }}$ century to denote the descendants of those who had colonised Ireland from the period of the Norman invasion to approximately that of the Reformation. Later colonists, and their descendants, who were for the most part differentiated from their predecessors by the profession of forms of the Protestant religion, were distinguished by the term New English.

2. In former times various forms of the spelling Terry were used: such as Tirry, Tyrry, Terrie or Tyrryfz for Terry. In this text the modern form of the spelling is used, for ease of reading.
Traditionally, the Old English had held themselves aloof from the conspiracies and rebellions of the Gaelic Irish. But during the first four decades of the $17^{\text {th }}$ century their loyalty was placed under increasing strain. They were excluded, in theory, from local as well as central government; heavy fines were imposed on prominent citizens refusing to attend Protestant services and even their titles to land like those of the Gaelic Irish, began to be questioned in courts that inevitably found for the crown. For periods, the English establishment took a pragmatic view, and the evidence shows that Catholics still held positions in civil authorities (Dickson 2005: 328). The Old English combined loyalty to England with a Catholicism that, since the Reformation, no longer attracted English support. They also controlled one-third of Irish land at a time when political acceptability was becoming dependant on religious conformity (Clarke 2000: 15).

The map of Cork city in 1600 (O'Brien 1974) shows the city to be walled and bounded on all sides by channels of the River Lee (Figure 1). The population of the City at this time would have been about 2,400 (Johnson 2002).

Figure 1. Pacanta Hibernia. Map of Cork of 1587

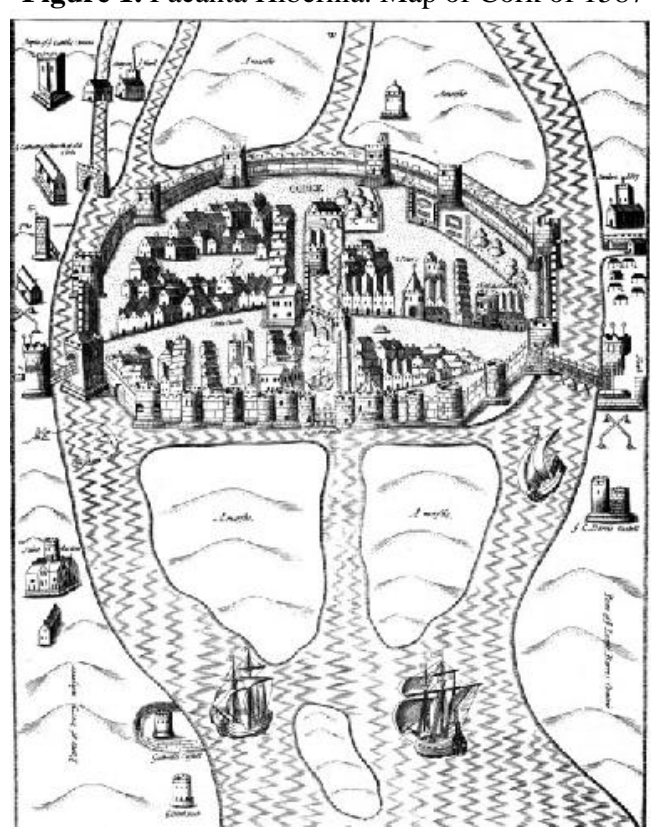

At the beginning of the $17^{\text {th }}$ century, the Terry families were in a powerful economic position in the city of Cork. Of the twelve or so families who came to dominate the civic and 
commercial life of Cork City, the grouping of Terry families was the most prominent in their allegiance to the crown of England and held significant sway in the political and civic affairs of the city. They were in a position to support laws that extended privileges, in trade and civic positions, to their children. In this they were able to exclude outsiders. Between the years 1612 and 1641, sixteen Terrys were sworn freemen of Cork City. These sixteen were the sons of Councillors and the merchant classes. Several were mayors of the city in this period. ${ }^{3}$ In the will of one James Tyrry, in 1618 , he refers to "The nation of the Terries" (Caulfield 1876: 1170-72). During the early part of the $17^{\text {th }}$ century they had extensive property in the city and land in rural areas

3. Once admitted to the freedom of a corporate town and entered on the register of freemen, a man was permitted to practice his trade and vote in parliamentary elections. Freedom was attained through the completion of an apprenticeship, through descent from one's father, by marriage into the family of a freeman or by grace of the mayor and corporation. around the City. There were at least fourteen different Terry families who were proprietors of 61 properties, in the city and suburbs. Of the 68 streets or lanes, 8 were named after Terrys. ${ }^{4}$

At the same time, they were merchants and had strong trading links with Europe. Their trading activity dated back to at least one hundred years earlier. Terrys dominated the civic and economic life of the city from the mid- $15^{\text {th }}$ century. As an example the trade carried out by William Terry for the year 1504 is shown in the accompanying table (Jones 2009):

4. This information is from a survey which provided a house-to-house record of Cork City before the rebellion in 1641 (Simmington 1942). In this list: The laneways in the City named after Terrys were: David Thirry's Lane (now Angel Lane), Robert Tirry's Lane (now Boland's Lane), James Tirry's Lane (now Kyle Street), David Tirry's Lane (now Old Bridewell Lane), Thirry's (Richard) Lane (now Phillips' Lane), Dominick Tirry's Lane (now Portney's Lane), David Terry fitz-Stephen's Lane (now Rowland's Lane), and William Tirry fitz-Patrick's Lane (now Wisdom Lane).

Table 1. Trading activity of William Terry in 1504

\begin{tabular}{|l|l|l|l|l|}
\hline Ship Name & Port & Destination & Date & \multicolumn{1}{|c|}{ Commodity } \\
\hline Franses & Bristol & from Ireland & $2 / 1 / 1504$ & $\begin{array}{l}\text { Hides, herring, } \\
\text { mantles, wax \& } \\
\text { hake }\end{array}$ \\
\hline $\begin{array}{l}\text { Jhesus } \\
\text { Bonavunture }\end{array}$ & unknown & from Bordeaux & $16 / 1 / 1504$ & wine \\
\hline Gabriell & Bristol & from Andalusia & $16 / 1 / 1504$ & wine \\
\hline Michaell & Bristol & from Andalusia & $16 / 1 / 1504$ & wine \& dates \\
\hline Mare & Penmarch & from Bordeaux & $17 / 1 / 1504$ & wine \\
\hline Marget & Bristol & to Bordeaux & $25 / 1 / 1504$ & $\begin{array}{l}\text { cloth of assize \& } \\
\text { hake }\end{array}$ \\
\hline $\begin{array}{l}\text { Mare } \\
\text { Belhous }\end{array}$ & unknown & from Algarve & $22 / 2 / 1504$ & fruit \\
\hline Trinite & Milford & from Ireland & $26 / 2 / 1504$ & hides \\
\hline James & Waterford & from Ireland & $1 / 3 / 1504$ & wax \\
\hline Trinite & Combe & from Algarve & $1 / 3 / 1504$ & wine \& fruit \\
\hline Trinite & Cork & from Ireland & $2 / 3 / 1504$ & herring \& hake \\
\hline Lenard & Waterford & from Ireland & $15 / 3 / 1504$ & $\begin{array}{l}\text { salmon, hake, } \\
\text { herring, mantles, } \\
\text { hides \& wax }\end{array}$ \\
\hline Trinite & Cork & to Ireland & $19 / 3 / 1504$ & pilores tinct \\
\hline
\end{tabular}




\begin{tabular}{|l|l|l|l|l|}
\hline Ship Name & Port & Destination & Date & \multicolumn{1}{|c|}{ Commodity } \\
\hline Lenard & Waterford & to Ireland & $28 / 3 / 1504$ & pilores tinct \\
\hline Marget & Bristol & from Bordeaux & $11 / 4 / 1504$ & woad \\
\hline Marget & Chepstow & from Chepstow & $18 / 4 / 1504$ & wine \\
\hline Katren & Bristol & from Ireland & $30 / 4 / 1504$ & $\begin{array}{l}\text { hides, lamb \& sheep } \\
\text { skins }\end{array}$ \\
\hline $\begin{array}{l}\text { Gelian } \\
\text { Bonaventur }\end{array}$ & unknown & from Spain & $30 / 5 / 1504$ & iron \\
\hline Mawdlen & Waterford & from Ireland & $25 / 6 / 1504$ & lamb \& sheep skins \\
\hline John & Cork & from Ireland & $18 / 7 / 1504$ & $\begin{array}{l}\text { sheep skins \& } \\
\text { mantles }\end{array}$ \\
\hline Sondaie & Waterford & from Ireland & $23 / 7 / 1504$ & sheep \& lamb skins \\
\hline John & Cork & to Ireland & $3 / 8 / 1504$ & $\begin{array}{l}\text { worked orchil \& } \\
\text { pilores tinct }\end{array}$ \\
\hline Fraunses & Bristol & to Algarve & $9 / 8 / 1504$ & cloth of assize \\
\hline Katren & Bristol & from Ireland & $12 / 8 / 1504$ & salmon \& sheep skins \\
\hline Katren & Bristol & to Ireland & $23 / 8 / 1504$ & pilores tinct \\
\hline Marget & Bristol & to Bordeaux & $5 / 9 / 1504$ & cloth of assize \\
\hline Mare & St. David's & from Ireland & $17 / 9 / 1504$ & $\begin{array}{l}\text { salmon, sheep skins } \\
\& \text { wax }\end{array}$ \\
\hline Lenard & Waterford & from Ireland & $22 / 9 / 1504$ & salmon \& herring \\
\hline
\end{tabular}

\section{Outbreak of Civil War and Cromwellian regime (1641-1660)}

In Ireland, the years 1641-1660 saw a revolution in land ownership that transformed the country's history. Virtually all Catholic landowners lost their estates. Many were dispossessed outright. Others, held to be guilty of lesser offences, received new grants of smaller amounts of land, in a group of western counties specifically set aside for the purpose. The turning point came in 1640-1641, when it seemed that the King, from whom the Old English had expected some favourable treatment, trading toleration for political and financial support, was about to lose power to a parliament that reflected much more closely the strong anti-Catholicism of ordinary Englishmen. Charles I himself blurred the question of loyalty by encouraging the army of the Gaelic Irish of Ulster to be used as a reserve against his English and Scottish enemies. In October 1641, the Ulster Irish rose in arms. They claimed they were defending the prerogative of the crown against its enemies in Parliament and elsewhere. The Old English, after several weeks of hesitation, agreed to join them (Connolly 1992: 7). Less than 10 years later, following The Cromwellian Wars and the widespread confiscation of land, Catholics lost out further. In 1644, when the Catholics where thrown out of the city of Cork, things went from bad to worse for the merchant family of Terrys: civic role and merchant and trading activities, were now substantially broken (Terry 2013: 73). In 1641, Catholics owned $59 \%$ of the profitable land in Ireland while in the city of Cork, Old English families owned about two-thirds of the property (Connolly 1992: 13). The Cromwellian regime of the 1650s changed the political rights with a discriminatory legislation. Penal Laws were instituted and lands confiscated to the Catholic families passed to Protestant ownership.

There is evidence of the continuing role of Terrys as members of the clergy since the early medieval period. In the $15^{\text {th }}$ and $16^{\text {th }}$ centuries there are a number of Terry priests in county Cork and Cloyne involved in episcopal affairs (Terry 2010). In the $17^{\text {th }}$ century there are references to some six Terry priests from Cork. The Terry's adherence to the Catholic faith was to prove to be their downfall by the mid $17^{\text {th }}$ century. In the 1640 s affairs became untenable for Catholic families and for royalist 
families, in Cork. To hold one's position and property one had to be Protestant and show constant good affection to Parliament. As Terrys were strongly Catholic and generally did not support the Reformation, the Cromwellian massacres also affected them. Records exist in this period reflecting the dramatic shift of status of the Old English towards the end of the $16^{\text {th }}$ century. A David Terry, Jesuit priest, lost his life in the siege of Limerick, in 1651 (O Connor 1753). He was the son of David Terry, mayor of Cork in 1614. Blessed William Terry, O.S.A. (1609-54), received his education for the priesthood on the Continent, and on his return to Cork, in 1638; he was appointed to Fethard in 1643 and became secretary to his Uncle, Bishop William Terry. He was arrested in 1654, and at his trial he acknowledged the power of the government on temporal matters but declared "in spiritual affairs wherein my soul is concerned, I acknowledge the Pope of Rome and my own superiors to have greater power over me than yours" (Hackett 2006: 112-57). He was convicted and hanged in the same year. Pope John Paul II beatified William Terry in 1993. His uncle, Bishop of Cork, also named William Terry, was born in about 1573. He studied in Belgium and was consecrated bishop in 1623 . He had to leave Cork in 1644 when the Catholics were expelled from the City (Terry 2013: 70).

\section{Restoration in 1660 and the end of the century}

On the restoration of the king in England in 1660 and the Act of settlement in 1662, Catholic land ownership increased to around 20 percent, more than twice what it had been at the end of the Cromwellian regime, but only a little over one-third of what it had been before 1641. What the Catholics had lost was divided between Old English Protestants and Cromwellian settlers (Connolly 1992: 15). In 1656, the Roman Catholic inhabitants were turned out of the City of Cork, and Protestant magistrates chosen to its government. In 1672, they were forbidden to enter Cork City or any walled town or fortification.

Towards the end of the century, Catholics responded to the accession of James II in 1685 with undisguised euphoria but he was soon deposed in the Glorious Revolution of 1688.
Their support for the short lived reign of King James II resulted in Terrys losing out further. After their initial expulsion from the city, some settled in the towns in the surrounding countryside. Some Catholic families were given the option of settling in either the Barony of Barrymore or the Barony of Muskerry. Others began to move abroad to France and Spain, where they already had trading links. A small number remained on in the city, continuing their trading and civic roles. Some of these converted to Protestantism. Still other Terrys, at this time, lost their lives in wars, in Ireland and on the continent.

In and around 1600 there were between twenty and thirty Terry families in Cork City, and around twelve families in the surrounding towns (particularly in Barrymore) that had significant power and wealth. A hundred years later, in 1700, the total number of Terry families recorded was sixteen or seventeen: only six families in Cork City as merchants, traders or involved in professions converted to Protestantism, the others, in the barony of Barrymore and Imokilly (Terry 2005: 240-1).

\section{Exile to Spain}

Cadiz was a very important centre in the colonial trade between Europe and the New World in the $18^{\text {th }}$ century, especially after the 1717 Monopoly of Trade when Casa de Contratación was moved from Sevilla to Cadiz. Among the immigrants attracted by the opportunities the city offered was the Terry family. The Terrys were welcome in Cadiz after having lost their possessions and having been persecuted for being Catholics in Ireland. On the other hand, Spanish laws would not have been unknown to the Terrys as there is evidence of their trading activities with this part of Spain at least dating back to 1500 . They were allowed to enter into colonial trade and proved their status of Hidalgo that the crown had granted them implying privileges and exemption from tributes and taxes. According to a Royal Decree in 1759, any Irish who had lived in Spain for more than ten years, or who had married a Spaniard, had the same rights as the native Spanish to trade and to property ownership (Fannin 2003). They already possessed extensive trading, shipping, military and diplomatic skills that they put to good use in their adopted country and developed as a 
successful group of traders in Cadiz and Malaga who played an important part in Spanish society and economy. Their role in political and economic affairs during the $18^{\text {th }}$ and $19^{\text {th }}$ centuries in Andalusia and the steps they followed in their social ascent will now be examined.

Three Terry branches came to Cadiz at the end of the $17^{\text {th }}$ century and during the first half of the $18^{\text {th }}$ century. The first branch belongs to the Marquis of Cañada (Marqués de la Cañada) who settled in Cadiz in 1689.The second branch refers to the brothers Domingo (Dominic) and Guillermo (William) who married Elena and Margarita McNamara. They established themselves in Cadiz and Malaga in 1723. The third branch, which we will name the Genoese branch, was founded by Andres Terrile who arrived in Cadiz from Finale (Liguria, Italy) about 1742.

\section{Marques de la Cañada Branch}

William Terry / Tirry or Tyrry (Limerick, 1663 - El Puerto, 1745) became the first Marquis of Cañada in 1729. His branch descended from Terry's in Cork city and Ballinterry, near Rathcormac His Genealogy is provided by James Terry (Lart 1938) and the Genealogy by Bryan O'Connor in 1753. Their parents were Juan (John) Terri and Maria Ronan who suffered in the siege of Limerick (AHPC: Sig. 997 Fol. 66-99). After the Glorious Revolution of 1689, William Terry settled in Spain and married to Isabel Sanchez de Silvera in 1707. His three brothers James, Patrick and Stephen left Ireland following King James II to France. ${ }^{5}$ James Terry (Limerick, 1660-Paris, 1725) was Athlone Herald to King James II in France. Stephen (born Limerick 1665) was Capitán de Dragones in Catalonia, whilst Patrick (Limerick 1667-) became brigadier of the king's army and captain of the Royal Guard (Terry 2005: 177). All them were granted the privilege of nobility by King James II, signed and sealed in Saint-Germain on 8 May 1694,

5. AHN: Proofs of noblesse of Guillermo Terry y Rouan, Knight of Santiago (1712). This document states that King James II granted this branch the privilege of nobility signed and sealed in SaintGermain on 8 May 1694. and in Spain the title of Knight of Santiago. ${ }^{6}$ In 1709, William Terry settled in Cadiz as a commercial agent. He claimed to have served voluntarily in the company of lieutenant general Bonifacio Manrique de Lara, and was graced with his naturalization in 1718 (Chauca 2003: 271). In 1719 he was allowed by Real Decree to trade with the Indies.

William Terry was the owner of the ship San Felipe (also known as The Lerri, The Terri or Tyrry), used in the war against Britain in the battle of Tolon together with four other trading ships from other wealthy owners in Cadiz (Terry 2013: 111). Another ship El Soberbio was admitted to cover the route to Veracruz, in 1749 , carrying iron, steel, wire, various fabrics, wax, paper, wine, liquor, oil, vinegar and boxes of books (Enríquez 2006). He was also an important land and real estate owner and known for his collection of ancient art and his large library (Beltrán 1995: 206-9). William was possessor of the title Marquis of Cañada in 1729 (AHN: CONSEJOS, 8977, A.1729, Exp.737). The king granted that two lions rampant to his coat of arm (Figure 2).

Figure 2. Coat of arms of the Marquis of Cañada. Source: AHN

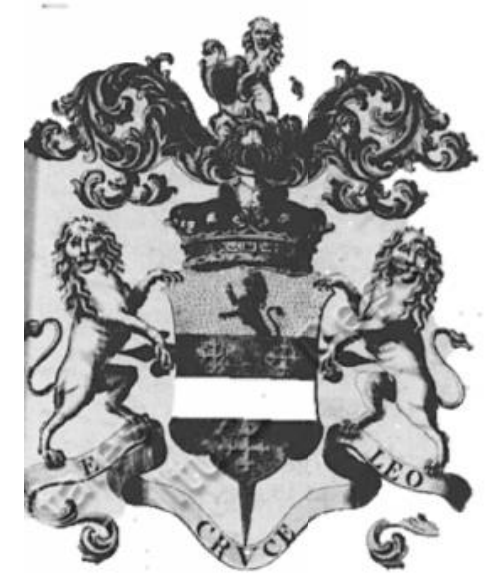

He served as royal representative of council affairs Alferez Mayor in Cadiz, a position

6. Patricio Terri y Rouan was made a Knight of Santiago in 1702. AHN: OM-CABALLEROS SANTIAGO, Exp. 8047. Esteban and Guillermo Terri in 1712.AHN: OM-CABALLEROS_ SANTIAGO, Exp.8045/8046. 
reserved for the most important citizens. Some of his descendants like Jose Maria Tirry Lacy and Guillermo Tirry Loinaz were army officers. Juan Tirry y Lacy was born in Spain but resided in Cuba and inherited the title Marquis of Cañada in 1824 (Fernandez 2007: 192). In 1759/60, Juan was captain of the Spanish armada and responsible for mapping the "Ysla de Pinos" (Cuba). In 1799 he went there with the mission of investigating whether the pine trees could be used for building ships in the Spanish navy. ${ }^{7}$ In honour of his contributions to geography, the northernmost point of the island was called Punta de Tirry. Juan Tirry was Engineer General in Havana, twice mayor of the city and Governor of Matanzas in $1816 .{ }^{8}$

Other members of this branch include Pedro Tyrry, son of Patrick Tyrry and Isauel Lambert, born in Spain in 1700 (Catálogo de las Disposiciones Testamentarias de Cadiz: 159-60). In 1736, PedroTyrry was appointed Director of the South Sea Company in London ${ }^{9}$ but he was ordered to return to Spain when the relations between the South Sea Company and the Spanish Government broke off and war was declared in 1739 (Donoso Anes 2007:140-41).

\section{The Second Branch: Domingo and Guillermo Terry Stackpoole}

The second Terry branch is described in detail in the Genealogy of Domingo (Dominick) (Limerick 1714 - Cadiz, 1784) and his brother Guillermo (William) Terry Stacpoole (born in Dublin,1715) authored by Bryan O'Connor in $1753 .{ }^{10}$ This genealogy

7. The map of "Ysla de Pinos" is preserved in the Indias Archive. Sig.: MP-LIBROS_MANUSCRITOS, 39.

8. Personal archive of Juan Tirry y Lacy. Archivo General de Indias. Sig.: ULTRAMAR, 32, N.4.

9. The South Sea Company known in Spain as Compañía Real del asiento was founded in 1711 as a company of merchants of Great Britain, trading to the South Seas and other parts of America. After the Treaty of Utrecht Queen Anne offered the Asiento de Negros to this company. One quarter of the profits were for Queen Anne and the other quarter for the King of Spain. The war of Jenkins' Ear brought an end to the company activities in the West Indies and South America. claims that all ancestors of this branch married other noble families and that they are descendants of Theodoric, Count of Alsace. It further states that their branch and the Marques de la Cañada branch are linked to the same ancestors of nobility in Cork, who suffered the confiscation of possessions and persecution for being Catholics, some of them having even lost their lives. In this respect, the genealogy states as follow:

Dominick Terry was Viscount of Limerick obtaining and enjoying great possessions in County Clare West, Stones hall, (...) with many other estates in place of key street and district all of which was stripped in the usurpation and tyranny of Oliver Cromwell. For his loyalty and defence of the Catholic faith (...) he was killed in the year of our Lord 1651 defending the city of Limerick by Oliver Cromwell's soldiers (Genealogy: 1).

According to this Genealogy, Dominick Terry had a brother, David Terry (1610-66) who belonged to the Society of Jesus, and was executed with Geoffrey Galway in Limerick after a long and desperate siege against Ireton.

Descendants of this branch held prominent positions in Cadiz and Malaga during the $18^{\text {th }}$ and $19^{\text {th }}$ centuries as Consuls, in the Military, and Insurance business. They married into other important families of Irish descent, such as the White, Power, Ryan, McCraigh, and Murphy but also Spanish families such as Villa, Artechea or López (See Figure 3). ${ }^{11}$ Guillermo and Domingo Terry Stacpoole, great grandsons of Dominick Terry, Viscount of Limerick, as mentioned above, were the first descendants of this branch settled in Cadiz about 1723. In 1757 (24 November) they were both declared noblemen of noble blood by Royal Decree of King Fernando VI. They were sons of Ignatius Terry Stacpoole who was appointed Deputy within the Dublin Consulate and responsible for businesses in Malaga.

10. This Genealogy belonged to Antonio Terry y Villa (1800-1880). It is currently preserved in the Terry Archive in Puerto Santa María. Courtesy of Elisa Terry.

11. Familiar archive Álvarez de la Villa-Terry. Some data about this branch were provided by Manolo Terry (Sevilla) 
Figure 3. Genealogy of Domingo and Guillermo Terry Stackpoole

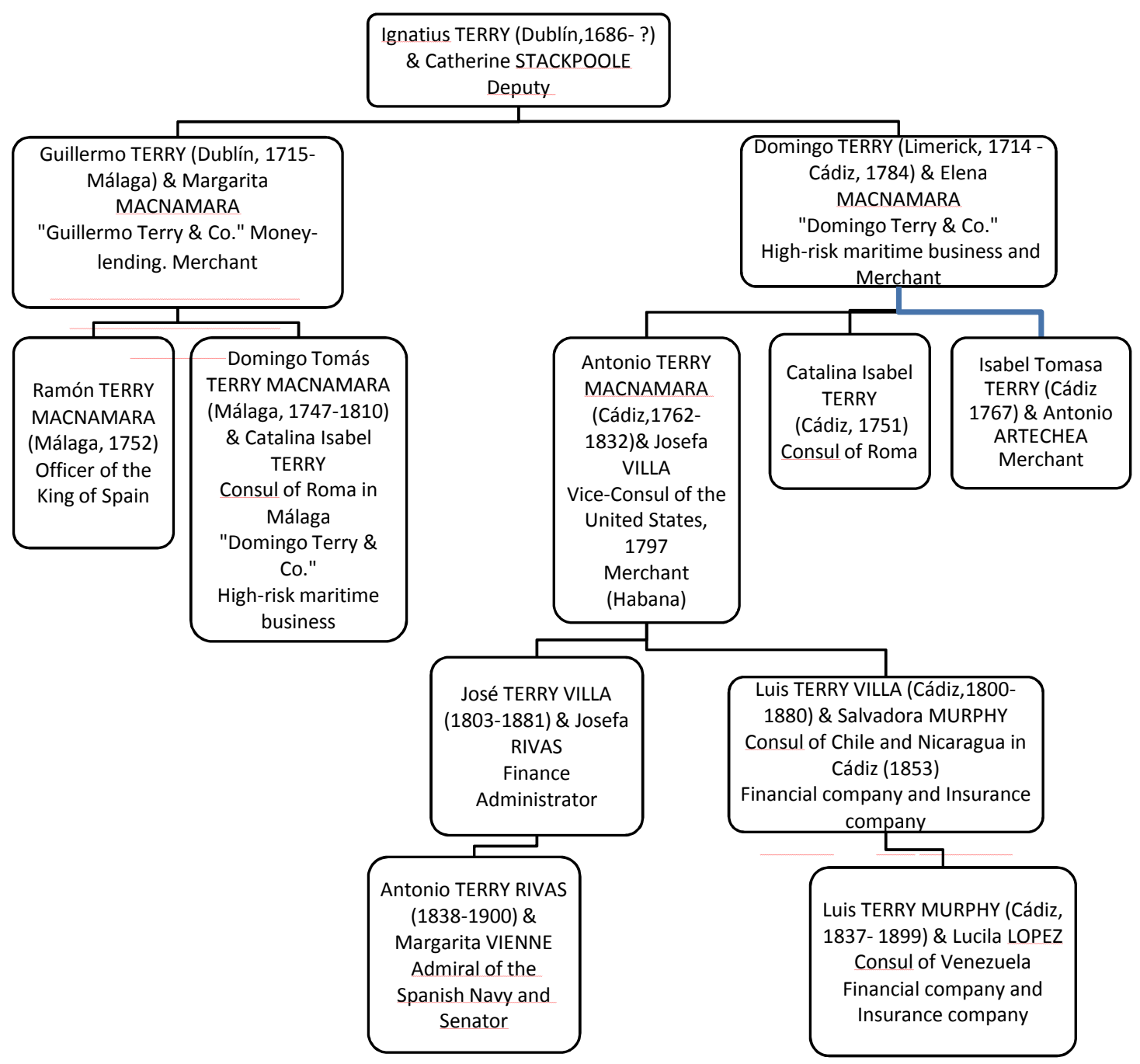

Guillermo Terry married Elena McNamara Terry and his brother Domingo, arrived in Cadiz a few years later, married Margarita McNamara Walsh. Margarita and Elena were cousins and belonged to a notorious and successful merchant family from Waterford settled in Spain. Domingo and Guillermo did well in mercantile affairs. In 1776 Domingo Terry and his son-in-law Domingo Tomás Terry McNamara owned the company "Domingo Terry \& Co" (AHPC, Ref. 4.516 F.1085-88) trading in wood (planks or staves for barrels of wine from New York, wood from Holland; Correo mercantil de España y sus Indias, 1792: 7) flour, rice, and wheat (Correo Mercantil de España y sus Indias, 1793: 31). In 1773 there were six ships belonging to Domingo Terry (Lario 2007: 221). Domingo
Tomás and Domingo Terry were also involved as the second largest investors with 986000 pesos (Bernal 1992: 469) in an insurance company covering high-risk maritime business during the second part of the $18^{\text {th }}$ century (Carrasco 1999: 296).

However, since 1778 many merchant and traders faced difficulties as Cadiz lost its special status in the trading monopoly. Colonial trade had begun to fall dramatically in spite of steps taken by the crown to improve the shipping industry, with the royal decree of 1765 of Free Trade (García-Baquero 1986). The impact on the Spanish economy of several wars - The Anglo-Spanish war and The Peninsular war against Napoleon - was dramatic and consequently, at the beginning of the nineteenth century, many companies went 
bankrupt, among them "Domingo Terry \& Co" in $1802 .{ }^{12}$ Another major company trading between Europe and America was owned by Guillermo Terry and called "Guillermo Terry \& Company". It was founded in 1770 in Malaga and remained successful for many decades (Mercurio de España 1790: 76).

Guillermo and Domingo Terry Stacpoole educated their sons in the Real Seminario de nobles de Madrid. ${ }^{13}$ Domingo had twelve children all born in Cadiz and most of them became merchants. One of them, Antonio Terry Macnamara (1762-1832) traded with Cuba, and in 1816 he sent his seventeen year old son, Domingo Terry Villa, to Havana because of business affairs about his Trade House. ${ }^{14}$ This Terry branch starts to occupy influential positions in the Consulate during the last third part of the $18^{\text {th }}$ century. Consuls had to have an outstanding social and economic status, experience in maritime trade and language skills. In 1785, the Consulate of

12. The will of Domingo Tomás Terry. AHPC: Sig. 430. F. 322-28.

13. Domingo Terry entered his sons in Real Seminario de nobles de Madrid Claudio and Guillermo Terry Macnamara in 1764, AHN: UNIVERSIDADES, 671-3, Exp.6. Guillermo Terry Stacpoole entered his son Diego and Domingo Tomásin (1758) and later Ramón and Guillermo (1763) according to AHN: UNIVERSIDADES, 671-3, Exp.7.

14. Archivo General de Indias, ULTRAMAR, 331, N.71.
Malaga is created and in the founding Royal Decree we find Guillermo Francisco Terry, son of Guillermo Terry Macnamara, as consul pontifical in Malaga (Campos Rojas 1978). His brother Domingo Tomás Terry was Consul of Roma (about 1788) and Consul of Etruria in Cadiz (1810) (AHN: ESTADO, 634, Exp.33). Also Antonio Terry Macnamara, son of Domingo Terry, was Vice-Consul of the United States in Cadiz (1797).

Towards the end of the $18^{\text {th }}$ century, the difficulties and risks faced by trading companies because of warfare induced the mercantile community to move to other economic activities. For example, Luis Terry Villa (Cadiz, 1800-1880) and his son Luis Terry Murphy (Cadiz, 1837-1899) made their appearance in the Consulate of Cadiz and played a major role in the industrialization of Andalusia with business initiatives in textile, insurance and banking sectors. In 1846, Luis Terry Villa founded the first textile factory in Spain with an investment of 150000 reales (Ramos 1887: 79). He and his son Luis Terry Murphy were major shareholders of the insurance company "Andalusia Lloyd" under "Luis Terry Villa e hijo", founded in 1864 covering maritime risks (Lepore 2008: 27293).They were also Directors of the savings bank "Monte de Piedad y Caja de Ahorros" and had invested their capital in land and houses in the city of Cadiz and surroundings (Table 2).

Table 2. Companies and saving bank: Luis Terry and son

\begin{tabular}{|l|c|}
\hline Company & Year \\
\hline Cotton Factory “Empresa Gaditana de Hilados y tejidos de Algodón” & 1846 \\
\hline Steamboat company “Empresa Gaditana de Buques de Vapor" & 1850 \\
\hline Director of the savings bank “ Monte de Piedad y Caja de Ahorros" & 1852 \\
\hline Empresa de Alhumbrado de gas & 1854 \\
\hline $\begin{array}{l}\text { Insurance company director in Cadiz } \\
\text { Director de La Aurora de España. Agricultural and cattle society }\end{array}$ & 1854 \\
\hline Lloyd andaluz & 1864 \\
\hline $\begin{array}{l}\text { President of Mining company “Minas la Caridad de Aznalcollar } \\
\text { Railway company “Camino del hierro" Madrid-Valencia }\end{array}$ & 1889 \\
\hline
\end{tabular}


Other members of this branch were army officers such as Antonio Terry Rivas (Cadiz, 1838 - Madrid, 1900) who served as Admiral to the Spanish Navy, Member of Parliament of Cadiz, Senator for the province of the Canary Islands and secretary to the Admiralty (AGMAB, 620/1199). He was decorated for actions in the War of Africa, War of Cuba and participated in missions to Mexico, Santo Domingo, and in the battle of Rio de Oro in Melilla (N. Africa). He also received medals for more than 20 scientific works he wrote on astronomy, navigation and mathematics, that contributed significantly to disseminating the latest scientific advances, and promoting modern methods of celestial navigation (García-Álvarez de la Villa 2014a: 69-95).

\section{The Third Branch: Genoese Branch}

Concerning the third branch from Genoa, ${ }^{15}$ its descendants settled in Spain, Cuba, Perú and Argentina. Andrés Terry Adriano son of Francesco Terrile of Genoa married Magdalena Jacome in Savona in 1723 (Diocesis Savona.

15. Data about this branch were provided by Juan Carlos de Terry and Elisa Terry. dispense matrimonial 1686. Sc XVII-XVIII) and, was the first to arrive in Spain from Finale (Genoa) at about 1740 (AHPC: Sig. 1349. Fol. 784-87). His grandson Santiago Terry Bucet, born in Cadiz in 1783, is well known for organising the committee of government and defence of the city against the French troops of Napoleon. Fernando Matías Terry (1821-1872) went into the wine business but Fernando A. de Terry Carrera (1861-1928) is the official founder of Bodegas Terry in 1883, an internationally renowned manufacturer of brandies (García-Álvarez de la Villa 2014b). Despite the difficulties of the wine industry in the late $19^{\text {th }}$ century, Fernando A. De Terry managed expansion and consolidation of the company during the early $20^{\text {th }}$ century while trading with Argentina, Uruguay, Mexico, South America, United States, Great Britain, Holland and Norway (El Heraldo de Madrid 6631, 1909: 5). In December 1901, he applied the brand "Fernando A. De Terry and Co" to "all sorts of cognac" (Industria $e$ Invenciones 15, 1902: 116). Fernando C. Terry del Cuvillo became owner of the world famous Carthusian horses, also known as "Pure Spanish Horses" in 1948.

Table 3. Genoese Branch

Francesco Terrile of Genoa.

Antonio Terrile (1723) \& Angela Maria Andriana. Finale, Liguria.

Andrés Terry Adriano \& Magdalena Jacome. Arrive in Cadiz ca. 1750

Santiago Terry Jacome (Officer of Royal Customs in Cadiz) \& Maria del Patrocinio Bucet (later she married Fernando Matías Ruiz)

Santiago Terry Bucet (1783-1862) \& Maria de las Dolores Gil de León

Company "Vda. de Ruiz e hijo" exports wine to Cuba

Fernando Matías Terry y Gil de León (1821-1872) \& Maria Teresa Carrera / Maria Teresa Urizar in 2nd marriage.

Wine business since 1855 in Puerto de Santa María.

Founder of "Bodegas Terry" in 1883:

Fernando A. de Terry y Carrera (1861-1928) \& Josefa Cubillo.

"Fernando A. de Terry and Co." (1910) exports wine to South America, United States, England, Holland and Norway.

Bodegas Terry in 1928:

Fernando C. Terry del Cuvillo (1887-1952).

Carlos J. Terry del Cuvillo (1892-)

Francisco Javier Terry del Cuvillo (1904- 2000) 
There are other prominent descendants of this Genoese branch in America. Don Tomás Terry y Adán, born in the city of Caracas, Venezuela, on the $24^{\text {th }}$ February 1808 was baptised in the parish church of San Pablo. He went to Cuba and established himself in Cienfuegos in 1830 (Santa Cruz y Mallen 1940/1950) and was the most successful of planters in Cuba in the mid $19^{\text {th }}$ century. $\mathrm{He}$ became the great boss of Cienfuegos, the "Cuban Croesus". He moved to New York in the 1860s and from there to Paris (Speck 2005: 50-86). Tomas married Doña Teresa Dorticos y Gómez de Leys, a native of Oberon, France, in 1837. The famous French decorator Emilio Terry was a descendant of Tomas. Of his children, Emilio Terry was the owner of two sugar estates, at the beginning of the twentieth century. On Cuba's independence he served as Minister of Agriculture. He also built the "Theatre Tomás Terry" in Cienfuegos. Fernando Belaún de Terry was born in 1912. His mother was Lucila Terry y García. He was President of Peru for two periods, between 1963 and 1968 and again between 1980 and 1985. A successful architect, he served in the chamber of deputies from 1945 to 1948. In Argentina, José Antonio Terry Costa was a government minister in the early $20^{\text {th }}$ century. His son, also named José Antonio was the famous Argentine painter.

\section{Conclusion}

At the beginning of the $17^{\text {th }}$ century, the Terry families of Cork held a powerful economic position in Cork city and were among the most prominent in their allegiance to the crown of England. Terrys held significant sway in the political and civic affairs and several were mayors in this period. At the same time, they were merchants and had strong trading links with Europe. They had a long trade relationship with Andalusia since the early modern period.

In 1644, Catholics were expelled from the city of Cork, and things went from bad to worse for the Terry merchant family. They completely lost their prominent civic positions and trading activities. After The Cromwellian Wars in Ireland (1649-1653) widespread confiscation of land from Catholics took place, to be divided between Old English Protestants and Cromwellian settlers. The Terry's adherence to the Catholic faith was a critical factor to be their downfall by the mid $17^{\text {th }}$ century. There is evidence of the continuing role of Terrys as members of the clergy since the early medieval period. In the $17^{\text {th }}$ century there are references of some Terry priests who suffered the consequences of Cromwellian persecution to the extreme of losing their lives. Subsequently, in this period some Terrys settled in the towns in the surrounding countryside. Others left Ireland and began to move abroad to France and Spain, where they already had trading links. Many of those who had supported King James II left Ireland for Europe after his defeat in the Glorious Revolution of 1689. A small number remained on in the city, continuing their trading and civic roles and many of these converted to Protestantism.

The Terry families, who immigrated to Spain, were welcome because of their status of persecuted Catholics form Ireland. They soon started to take advantage of the business opportunities that Spain offered with respect to commerce with the West Indies. The Bourbons, united by the same faith, granted the Terrys privileges based on their proof of nobility. They already possessed extensive trading, shipping, military and diplomatic skills and when they settled in Cadiz they prospered in colonial trade and played important roles in the industrialization of Andalusia in the $19^{\text {th }}$ century. Some of them were knighted in the military Order of Santiago and they further increased their civil status through intermarriages with other families that played an important part in Spain's society and economy. The remarkable rise of the three Terry branches considered in this paper into the oligarchies of Cadiz and Malaga, and their influence in the economic framework of these cities is highlighted by the positions they start to occupy in the Consulate during the last third of the $18^{\text {th }}$ and $19^{\text {th }}$ centuries. Some Terrys moved from Spain to Latin America during the $18^{\text {th }}$ century where they also gained considerable social, economic and political status. Towards the end of the $19^{\text {th }}$ century, Terrys in Cadiz (Puerto de Santa Maria) became well known in the wine industry as exporters of sherry. 


\section{Works Cited}

Beckett, J. 1966. The Making of Modern Ireland 1603-1923. London: Faber and Faber.

Beltrán, José and Gascó, Fernando. 1995. La Antigüedad como argumento. Historiografía de arqueología e historia antigua en Andalucía. Sevilla: Librería Scriptorium S.C.

Bustos Rodriguez, Manuel. Cadiz en el sistema atlántico. La ciudad y su actividad mercantil (1650-1830). Madrid: Ed. Silex.

Carrasco González, M.G. 1999. "El negocio de los seguros marítimos en Cádiz a finales del siglo XVIII". Hispania LIX/1. No 201. 269-304.

Campos Rojas, Maria Victoria.1978. "Notas sobre el consulado marítimo y terrestre de Malaga". Revista Jábega. No 23. Málaga. 38-43.

Caulfield, Richard.1876. The Council Book of the Corporation of the City of Cork from 1609 to 1643, and from 1690 to 1800. J. Guilford: Billing \& Sons. 1170-2.

Chauca García, Jorge. 2003. "Irlandeses en el comercio gaditano americano del setecientos”. I Coloquio Internacional Los Extranjeros en la España Moderna. Málaga. V. I. 267 - 77.

Clarke, Aidan. 2000. The Old English in Ireland, 1625-1642. Dublin: Four Courts Press.

Connolly, S.J. 1992. Religion, Law and Power - the making of Protestant Ireland, 1660-1760. Oxford: Claredon Press.

Dickson, David. 2005. Old World Colony Cork and South Munster 1630-1830. Cork: University Press. 3-28.

Donoso Anes, Rafael. 2007. "Un análisis sucinto del Asiento de esclavos con Inglaterra (1713-1750) y el papel desempeñado por la contabilidad en su desarrollo”. Anuario de Estudios Americanos. Vol. 64. No 2. 10544.

Fernández Moya, Rafael. 2007. "The Irish Presence in the History and Place Names of Cuba”. Irish Migration Studies in Latin America. Vol.5. No 3.189-97.

Enríquez Macías. 2006. "El Soberbio. Naufragio y rescate de un navío en el siglo XVIII”. Revista de Historia Naval 93. Año XXIV. Madrid: Servicio de Publicaciones de la Armada. 33-56.

Fannin, S. 2003. "The Irish community in eighteenth-century Cadiz”. In O’Connor, and Lyons, Mary Ann (eds.) Irish Migrants in Europe after Kinsale, 1602-1820. Dublin: Four Courts Press. 135-48.

Foster, R.F. 1988. Modern Ireland 1600-1972. London: Allen Lane. Penguin Press.

García-Álvarez de la Villa, Beatriz. 2014a. “Antonio Terry y Rivas (1838-1900): vida y obra científicomatemática de un marino ilustre”. Revista de Historia Naval 127. Año XXXII. Madrid: Servicio de Publicaciones de la Armada. 69-95.

2014b. "Fernando A. de Terry y Carrera (1861-1928)". Diccionario Biográfico Español. Madrid: Publicaciones de la Real Academia de Historia. RAH.

García-Baquero, Antonio. 1896. Andalucía y la carrera de indias (1492-1824). Barcelona: Editoriales Andaluzas Unidas. S. A.

Hackett, Michael Benedict. 2001. A Presence in the Age of Turmoil, English, Irish and Scottish Augustinians in the Reformation and Counter-Reformation. Villanova: Augustinian Historical Institute.

Jones, Evan. 2009. Bristol 'particular' accounts, 1504, TNA E122 199/1. University of Bristol.

Johnson, Gina. 2002. The Laneways of Medieval Cork. Cork: Cork City Council.

Lario, Maria del Carmen. 2007. "The Irish traders of eighteen-century in Cadiz. Edited by David Dickson, Jan Parmentier and Jane H. Ohlmeyer, Irish and Scottish Mercantile Networks in Europe and Overseas in the seventeenth and eighteenth centuries. Gent: Academia Press. 221.

Lart, Charles Edmunt. 1938. "The Pedigrees and Papers of James Terry", Athlone Herald (1690-1725). Exeter: W. Pollard

Lepore, Amedeo. 2008. "Commercio e assicurazionia Cadice traetà moderna e contemporanea: la presenza dei Lloyd's”. Revista storica italiana.V.120. No1. 272-93.

O’ Brien, Michael. 1974. Drawings of Cork. Dublin: O’Brien Press.

Ramos Santana, Alberto.1887. La burquesía gaditana en la época isabelina. Cadiz: Cátedra Adolfo de Castro.

Recio Morales, Óscar. 2012. “Un estado de la cuestión”. In Redes de nación y espacios de poder: la comunidad irlandesa en España y la América española 1600-1825. Valencia: Albatros ediciones. 37-52.

Santa Cruz y Mallen, Francisco Xavier de. 1940-50. Historia de familias cubanas. 6 Vols. Havana: ed. Hercules.

Simmington, R. C. 1942. The Civil Survey 1654-1656: County Waterford, Vol. VI, with appendices. Also Valuations, 1663-1664, for Waterford and Cork Cities. Dublin: The Stationary Office. 
Terry, Kevin. 2005. The Terrys of Cork. Merchant Gentry (1600-2000). Midleton: Litho Press. 2010. "Aspects of settlement of an hereditary clerical family in the medieval period: the Terrys of Cork". Journal of the Cork Historical and Archaeological Society. Vo. 115. Cork: Margaret Lantry. 23-30. . 2013. The Terrys of Cork (1180-1644). Andover: Phillimore \& Co.

Speck, Mary. 2005. "Prosperity, Progress, and Wealth: Cuban Enterprise during the Early Republic, 1902-1927". Cuban Studies. Vol 36. 50-86.

Windle, John. 1847. Sarsfield and other Papers relating to Cork. Blair's Castle.1.

\section{Newspapers}

Mercurio de España. 1790. Madrid. (October 1790).76.

Correo Mercantil de España y sus Indias. (November,1792). 7.

Correo Mercantil de España y sus Indias. 1793. No 4. (January 14, 1793).31.

Industria e Invenciones. 1902. No 15. (April 12, 1902).116.

El Heraldo de Madrid. 1909. No. 6631 (January 24, 1909).5.

\section{Archival Sources}

City of Cork- Survey of Valuation, (circa AD 1663-1664)

Richard Terry: Bibliotheque National of Paris (microfilm copy in the National Library of Ireland). Ref. n548 p135. Familiar archive: Elisa Terry, Juan Carlos Terry, Manolo Terry, Alvarez de la Villa Terry.

Bryan O Connor, The Genealogy and Ensigns Armorials of the Terry family, (unpublished), 1753

Archivo Histórico Provincial de Cádiz (AHPC): Sig. 997. Fol. 66-99.

Domingo Tomás Terry, Domingo. Archivo Histórico Provincial de Cádiz (AHPC): Sig. 430. Fol. 322-28.

The will of Santiago Terry Jacome. Archivo Histórico Provincial de Cádiz (AHPC): Sig. 1349. Fol. 784-87.

Pedro Tyrry. ArchivoHistórico Provincial de Cadiz (AHPC): Catálogo de las Disposiciones Testamentarias de Cadiz. Folio 159-160.

Patricio Terri y Rouan. Archivo Histórico Nacional (AHN): OM_CABALLEROS_SANTIAGO, Exp. 8047.

Esteban Terri y Rouan.Archivo Histórico Nacional (AHN): OM-CABALLEROS_SANTIAGO, Exp. 8045.

Guillermo Terri y Rouan. Archivo Histórico Nacional (AHN): OM-CABALLEROS_SANTIAGO, Exp. 8046.

Marqués de la Cañada. Archivo Histórico Nacional (AHN): CONSEJOS, 8977, A.1729, Exp.737.

Domingo y Guillermo Terry Macnamara. Archivo Histórico Nacional (AHN), UNIVERSIDADES, 671-3, Exp. 6.

Archivo Histórico Nacional (AHN): ESTADO, 634, Exp.33.

Antonio Terry y Rivas. Archivo General de la Marina “Álvaro de Bazán” (AGMAB): 620/1199.

Juan Tirry y Lacy. Archivo General de Indias. Sig.: MP-LIBROS_MANUSCRITOS, 39.

Juan Tirry y Lacy. Archivo General de Indias. Signatura: ULTRAMAR, 32, N.4.

Received 29 August 2015 Last version 9 December 2015

Beatriz García-Álvarez de laVilla is piano teacher at the Superior Conservatory of Music in Granada. She studied Geography and History at the University of Oviedo, and has a Master in Musical Heritage from the University of Granada. In 2014 she published in Revista de Historia Naval on navy admiral Antonio Terry y Rivas (1838-1900), from whom she is a descendent, and contributed to the Diccionario Bibliográfico Nacional (entry: Terry). Currently, she is investigating another important figure of Irish descent in 19th century Spain, Guillermo Morphy (Conde de Morphy), as part of a doctoral thesis.

Kevin Terry. A chartered engineer and Fellow of Engineers Ireland, Kevin Terry was formerly Cork City Engineer. He has an M.A. in local history from University College Cork and has published on the history of the Terrys - a Cork merchant family in former times. Kevin is Chairperson of the Cloyne Literary and Historical Society. 